\title{
Synthesis of 5-(4-bromophenyl) - 4, 6- dichloropyrimidine Shanshan $\mathrm{Hou}^{1}$, Chen Chen ${ }^{1}$, Ping Wang ${ }^{1, \mathrm{~b},{ }^{*}}$, , Chao Sun ${ }^{1}$, Pengwu Zheng ${ }^{1}$ and
Shan $\mathrm{Xu}^{1, \mathrm{a},{ }^{*}}$
}

${ }^{1}$ School of Pharmacy, Jiangxi Science \& Technology Normal University, Nanchang 330013, China

*ashanxu9891@126.com, b439711557@qq.com

Keywords:Dimethyl2 - ( 4 -bromophenyl ) malonate; 5 - ( 4 - bromophenyl ) pyrimidine - 4 , 6 - diol; 5 - ( 4 - bromophenyl ) -4, 6 - dichloropyrimidine; Synthesis.

Abstract. The pyrimidine compounds are a class of nitrogen-containing heterocyclic compounds. 5-(4-bromophenyl)-4, 6-dichloropyrimidine is an important intermediate in the synthesis of pyrimidines, dimethyl2-(4-bromophenyl) malonate and 5-(4-bromophenyl) pyrimidine-4,6-diol are important intermediates in compound 1. In this work, a rapid synthetic method for compound 1 was established. The compound 1 was synthesized from the commercially available methyl 2-(4-bromophenyl) acetate through three steps. The structure was confirmed by MS and 1HNMR. Furthermore, the synthetic method was optimized. The total yield of the three steps was $52.8 \%$ (calculated from methyl 2-(4-bromophenyl) acetate).

\section{Introduction}

5 - (4-Bromophenyl)-4, 6- dichloropyrimidine (1) is a key intermediate and has a wide range of applications in the pharmaceutical and chemical fields. $\mathrm{N}-(5-(4-$ bromophenyl $)-6-$ chloropyrimidin $-4-\mathrm{y} 1$ ) butane-1- sulfonamide ${ }^{[1]}$ (2) was designed and synthesized basing on 5-(4-bromophenyl)-4, 6-dichloropyrimidine. 5-(4-bromophenyl)-4-(2-((5-bromopyrazin-2-yl) oxy) ethoxy) -6-chloropyrimidine ${ }^{[2]}$ (3) was synthesized according to 5- ( 4 -bromophenyl )-4, 6-dichloropyrimidine. Bolli $\mathrm{M}$, Boss $\mathrm{C}$, Clozel $\mathrm{M}^{[3]}$ et al. used 5- ( 4- bromophenyl )-4, 6-dichloropyrimidine as a key intermediate to synthesize 1- ( 5 - ( 4 - bromopheny 1$)$ - 6chloropyrimidin -4- yl ) - N - ( 2- methoxyethyl ) methanesulfonamide ${ }^{[4]}$ (4). The structures of representative compounds were shown in Fig. 1

As have been reported, 5-(4-bromophenyl)-4, 6-dichloropyrimidine was an important intermediate for synthesis those active compounds. Matulenko M A, PaIght E S, Frey RR, et al ${ }^{[5]}$ make 5-(4-bromophenyl)-4, 6-dichloropyrimidine in good yields. CuccIa S J ${ }^{[6]}$ and $\mathrm{K}$ hetrapal C L ${ }^{[7]}$ synthesized some similar compounds. In this paper, we summarized and optimized the above methods and the synthetic methods reported in the literature. Using methyl 2-(4-bromophenyl) acetate to synthesize dimethyl 2-(4-bromophenyl) malonate, then synthesize 5-(4-Bromophenyl) pyrimidine-4, 6-diol and 5-(4-bromophenyl)-4, 6-dichloropyrimidine. 
<smiles>Clc1ncnc(Cl)c1-c1ccc(Br)cc1</smiles>

1<smiles>Clc1ncnc(OCCOc2ncc(Br)cn2)c1-c1ccc(Br)cc1</smiles><smiles>CCCNS(=O)(=O)Nc1ncnc(Cl)c1-c1ccc(Br)cc1</smiles>

2<smiles>COCCNS(=O)(=O)Nc1ncnc(Cl)c1-c1ccc(Br)cc1</smiles>

4

Fig.1 Structures of the intermediate and some drugs or active compounds containing the intermediate

\section{Materials and methods}

The Melting point(M.P) of compounds was taken by X-4 type digital melting point apparatus manufactured by Beijing Tektronix, Inc. (temperature Degree without more positive).Mass spectra (MS) were taken in ESI mode on Agilent 1100 LC-MS. H NMR was taken by a Bruker ARX-300 NMR analyzer. TLC analysis was carried out on silica gel platesGF254 (Qin dao Hai yang Chemical, China) .All the materials were obtained from commercial suppliers and used without purification, unless otherwise specified.

\section{Synthesis of compounds}<smiles>COC(=O)Cc1ccc(Br)cc1</smiles><smiles>Clc1ncnc(Cl)c1-c1ccc(Br)cc1</smiles>

The structures and the synthetic route were shown in Scheme 1.

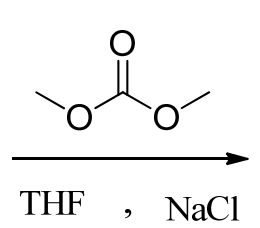

1<smiles>COC(=O)C(C(=O)OC)c1ccc(Br)cc1</smiles>

6<smiles>Oc1ncnc(O)c1-c1ccc(Br)cc1</smiles>

Scheme1. The synthetic route of compound 1

Reagents and conditions:(a) THF, $\mathrm{NaCl}, 25^{\circ} \mathrm{C}-27^{\circ} \mathrm{C}, 15 \mathrm{~h}$; (b) Anhydrous methanol, Na, semiamitraz chloride, 3.5h; (c) Phosphorus oxychloride. 


\section{Dimethyl 2-(4-bromophenyl) malonate (6)}

A solution of methyl 2-(4-bromophenyl)acetate (5) $(206.8 \mathrm{~g}, 0.9 \mathrm{~mol})$ in THF $(400 \mathrm{~mL})$, then it was added drop-wise to a suspension of sodium hydride $(65.0 \mathrm{~g}, 2.71 \mathrm{~mol})$ in THF solution $(1000 \mathrm{~mL})$ at room temperature, control the drip rate and the temperature was kept $25 \sim 27{ }^{\circ} \mathrm{C}$, when dropping was completed, keep the temperature for $1 \mathrm{~h}$, then dimethyl carbonate (DMC) $(325.1 \mathrm{~g}, 3.6 \mathrm{~mol})$ was added, keep the reaction for $14 \mathrm{~h}$. After cooling to $-10{ }^{\circ} \mathrm{C}$, the solution is adjusted to $\mathrm{pH} 6 \sim 7 \mathrm{using}$ hydrochloric acid (36\%) then removed THF under reduced pressure, ethyl acetate $(1600 \mathrm{~mL})$ was added to the solution, the organic phase was washed with hydrochloric acid solution $(1 \mathrm{~mol} / \mathrm{L}, 36 \%)$ saturated brine and was dried by magnesium sulfate, then it was distilled under reduced pressure to afford yellow oil. The yellow oil was solidified by cyclohexane, after mixture was filtered and driedto obtain yellow solid, then re-crystallized with ethanol- acetone $(5: 2)$ to obtain $\mathbf{6}$ as white solid (192.9 g).yield: 72.3\%. M.p.77-79 ${ }^{\circ} \mathrm{C}, \mathrm{MS} ; 308.8[\mathrm{M}+\mathrm{Na}]^{+}, 596.7[2 \mathrm{M}+\mathrm{Na}]^{+}$.

\section{5-(4-Bromophenyl) pyrimidine-4, 6-diol (7)}

Sodium $(46.9 \mathrm{~g}, 2.0 \mathrm{~mol})$ was slowly added into methanol $(600 \mathrm{~mL})$ at $0^{\circ} \mathrm{C}$. Dimethyl $-2-(4$ -bromophenyl ) malonate $(192.9 \mathrm{~g}, 0.67 \mathrm{~mol})$ was dissolved in methanol $(380 \mathrm{~mL})$ added into the solution of sodium methoxide, after dropping, keep the reaction for $1 \mathrm{~h}$ at roo was added, heated to $40{ }^{\circ} \mathrm{C}$ for $3.5 \mathrm{~h}$. After cooling to room temperature, methanol was distilled off under reduced pressure, the solution of citric acid was added into the residue and stirred for 1 hours. The precipitated solid was suction filtered, and the solid $\mathrm{w} \mathrm{m}$ temperature, then formamidineas washed with water, then dried to give a yellow solid. The crude product was added into cyclohexane $(900 \mathrm{~mL})$ was stirred for $3 \mathrm{~h}$ at room temperature, then the precipitated solid was suction filtered, the solid was washed with cyclohexane and dried to obtain7 as light yellow solid (149.1 $\mathrm{g}, 84.4 \%)$. M.p.178-180 ${ }^{\circ} \mathrm{C}$; MS; 269.0[M+H ${ }^{+}, 288.9[\mathrm{M}+\mathrm{Na}]^{+}$.

\section{5-(4-Bromophenyl)-4, 6-dichloropyrimidine (1)}

5-(4-Bromophenyl) pyrimidine-4, 6-diol $(53.4 \mathrm{~g}, 0.2 \mathrm{~mol})$ was slowly added into $\mathrm{POCl}_{3}(427 \mathrm{~mL})$, refluxed for $8 \mathrm{~h}$. $\mathrm{POCl}_{3}$ was distilled off under reduced pressure, then the black viscous residue was poured into ice water $(1000 \mathrm{~mL})$, The solution was adjusted to $\mathrm{pH} 9 \sim 10$ using potassium carbonate. The product was filtered off, washed with water and dried under reduced pressure to afford 5-(4-bromophenyl)-4, 6-dichloropyrimidine (1) as white solid (52.6 g, 86.5\%). M. P. $101-102{ }^{\circ} \mathrm{C}$, MS: $302[\mathrm{M}+\mathrm{H}]^{+}$; $1 \mathrm{H}$-NMR (300 MHz, DMSO-d 6 ) $\delta 8.96(\mathrm{~s}, 1 \mathrm{H}, \mathrm{Ar}-\mathrm{H}), 7.72(\mathrm{~d}, \mathrm{~J}=8.5 \mathrm{~Hz}, 2 \mathrm{H}$, Ar-H), 7.39(d, J = 8.5Hz, 2H, Ar-H).

\section{Conclusions}

In conclusion, 5- ( 4- bromophenyl )- 4, 6-dichloropyrimidine was synthesized from the commercially available methyl 2-(4-bromophenyl) acetate through three steps. The synthetic method of compound 1 and the reactions conditions were optimized. Its structure was confirmed by MS and ${ }^{1}$ HNMR spectrum.

\section{Acknowledgments}

We gratefully acknowledge the generous support provided by The National Natural Science Funds (No. 81460527), Project supported by the Natural Science Foundation of Jiangxi Province (No. 20142BAB215020), Doctoral Scientific Research Foundation of Jiangxi Science \& Technology Normal University and Program of Key Laboratory of Drug Design and Optimization, Jiangxi Science \& Technology Normal University(300098010306) and College Students' Science and Technology Innovation Project of Jiangxi Province and Graduate Students' Innovation Project of Jiangxi Science \& Technology Normal University(YC2014-X25).

\section{References}

[1] Bolli M H, Boss C, Bin kert C, et al. The discovery of N - [ 5 - ( 4 - bromopheny 1$)$ - 6 - [ 2[ ( 5 -bromo -2 -pyrimidiny 1) oxy ] ethoxy ] - 4-pyrimidinyl ] - $\mathrm{N}^{\prime}$ - propylsulfamide ( Macitentan ), 
an orally active, potent dual endothelin receptor antagonist [J]. Journal of medicinal chemistry, 2012, 55(17): 7849-7861.

[2] Murugesan N, Barrish J C, Gu Z, et al. Isoxazolyl endothelin antagonists: U.S. Patent 6,043, 265 [P]. 2000 -3-28.

[3] Bolli M, Boss C, Clozel M, et al. Pyrimidine-sulfamides and their useas endothelian receptor antagonist: U.S. Patent 7,452,896[P]. 2008-11-18.

[4] Matulenko M A, Paight E S, Frey R R, et al. 4 - Amino - 5 - aryl - 6 - arylethynylpyrimidines: Structure -activity relationships of non-nucleoside adenosine kinase inhibitors [J]. Bioorganic \& medicinal chemistry, 2007, 15(4): 1586-1605.

[5] DiStefano P, Napper A, Curtis R, et al. Sulfonamides and uses thereof: U. S. Patent Application 11/098, 315 [P]. 2005 -4-4.

[6] Cuccia S J, FlemingLB, France D J. A novel and efficient synthesis of 4- phenyl -2 chloropyrimidines from acetophenone cyanoimines [J]. Synthetic communications, 2002, 32(19): 3011-3018.

[7] Khetrapal C L, Kun war A C, Arumugam S. The use of two nematic solvents in the determination of molecular structure of systems providing deceptively simple spectra [J]. Organic magnetic resonance, 1984, 22(11): 707-709. 